\title{
A SIMPLE MODEL OF AN ECONOMICAL PROBLEM IN THE MATHEMATICA ENVIRONMENT
}

\author{
FAJKUS Martin, CZ
}

\begin{abstract}
The article deals with a simple problem from microeconomics. According to the given data and taking into account the character of the problem an appropriate mathematical model is created, the way how to solve it is shown and the result is properly interpreted. Further it is shown how the problem could be solved by the help of IT, especially the Mathematica environment. The use of computers in teaching is now very common in different subjects not only at technical universities. In the article the relationship between mathematical symbols, economical terms and real-life terminology is discussed.
\end{abstract}

Key words: microeconomics, Mathematica, mathematical model, computers in teaching

\section{JEDNODUCHÝ MODEL EKONOMICKÉ ÚLOHY V PROSTŘEDÍ MATHEMATICA}

\section{Resumé}

Článek se zabývá jednoduchou úlohou z mikroekonomie. Podle zadaných údajů a berouc v potaz charakter problému, je vytvořen př́slušný matematický model. Je ukázán postup jeho řešení a výsledek je patřičně interpretován. Dále je ukázáno, jak je možné danou úlohu řešit pomocí IT, zvláště pak v prostředí Mathematica. Užití počítačů ve výuce je již zcela běžné v mnoha oborech nejenom na technických univerzitách. V článku je také diskutován vztah mezi matematickými symboly, ekonomickými pojmy a terminologií z běžného života.

Klíčová slova: mikroekonomie, Mathematica, matematický model, počítače ve výuce

\section{Introduction}

It is often emphasized to teach a subject in context with other subjects and/or to show many applications. That is why in microeconomics there are many examples from business, in mathematics teachers include "word problems" which should simulate real-life situations. But do the students understand the relationship between mathematical and microeconomical terms? Calculus and some other topics are not always obligatory (e.g. (4)) and so many students do not know e.g. that marginal costs can be calculated as a derivative of total costs. Of course, they may see a problem of how to get the (mathematical) function from data obtained from, let's say, a questionaire. Do they know that data in the table, graph of a curve and an equation $y=f(x)$ may represent the same function? Many times it happens, that students solve the same problem in a different way in mathematics than in microeconomics without knowing the relationship between those procedures. To show that mathematics in not useless, it is usually the teacher of mathematics, who has to show mathematical applications to other subjects.

In this paper we will simulate a simple real-life problem. Similar problems could be found in textbook on mathematics for students of economics, e.g. (2), (5). The problem will be solved in a traditional way without any computer aid and subsequently by the help of IT. Because the use of computers in teaching of different subjects, not excluding mathematics and economics, is now quite common (e.g. (6)), students will certainly be familiar with such an approach.

From an economical point of view, it is a cost-revenue-profit problem, according to mathematical terms the task is to find a (global) maximum of a one variable function. Because in the real-life problems the data come from observation or surveys, there are no functions given as an input. 


\section{Problem formulation}

In every business there are aims to have minimal costs and maximal profit. Let's say, that a company producing and selling certain good knows from previous market research what is a demanded number of products with respect to the price for some values; the data are shown in Tab. 1a.

The company also knows what are the total costs to produce specified number of products; these data are shown in Tab. $1 \mathrm{~b}$.

Table 1: a) Demand and b) Total costs (source: own)

a) DEMAND

\begin{tabular}{|cc|}
\hline $\begin{array}{c}\text { Number of products } \\
\text { (in hundreds of pcs.) }\end{array}$ & $\begin{array}{c}\text { Price } \\
\text { (in thousands of } \\
\text { monetary units) }\end{array}$ \\
\hline \hline 5 & 90 \\
\hline 10 & 80 \\
\hline 15 & 70 \\
\hline 20 & 60 \\
\hline 25 & 50 \\
\hline 30 & 40 \\
\hline 35 & 30 \\
\hline 40 & 20 \\
\hline
\end{tabular}

b) TOTAL COSTS

\begin{tabular}{|cc|}
\hline $\begin{array}{l}\text { Number of products } \\
\text { (in hundrerds of pcs) }\end{array}$ & $\begin{array}{c}\text { Price } \\
\text { (in thousands of } \\
\text { monetary units) }\end{array}$ \\
\hline \hline 5 & 656 \\
\hline 10 & 725 \\
\hline 15 & 806 \\
\hline 20 & 900 \\
\hline 25 & 1006 \\
\hline 30 & 1125 \\
\hline 35 & 1256 \\
\hline 40 & 1400 \\
\hline
\end{tabular}

Assuming that all produced goods will be sold, how many products the company should produce to obtain maximal profit? What will be this maximal profit?

\section{Economical analysis}

From the economical point of view, the profit $\boldsymbol{P}$ is the difference between the total income (revenue $\boldsymbol{R}$ ) and the total costs $\boldsymbol{C}$. Simply: $\boldsymbol{P}=\boldsymbol{R}-\boldsymbol{C}$.

While total costs are all expenditures needed to produce the goods (expenses for raw materials, tools, salary, ...), the revenue comes from selling the products. The market price $\boldsymbol{p}$ depends not only on the producer (for how much he wants to sell), but also on the consumers (for how much they are willing to buy). The relationship between these two entities is described by the demand function $\boldsymbol{D}$. Multiplying the number of products $\boldsymbol{q}$ by the market price $\boldsymbol{p}$ for a single unit results in the total revenue: $\boldsymbol{R}=\boldsymbol{q} \cdot \boldsymbol{p}$

Thus both revenue and costs differ from the number of products. In consequence, the total profit is also a function of the number of products:

$P=q \cdot p-C$

What is the certain number of products, by which the profit will be maximal?

\section{Mathematical solution}

To solve the problem mathematically we need to have a demand function and the function of total costs. In mathematics the function is usually denoted always as $y=f(x)$. So the symbol $x$ represents the independent variable, while $y$ the dependent variable.

Let's denote the demand function as $y_{1}$ and the total costs function as $y_{2}$. The first approximation could be linear, so to get those functions, we need to calculate the appropriate coefficients. For linear regression $y=a x+b$ using the least square method 
$a=\frac{n \cdot \sum x_{i} y_{i}-\sum x_{i} \sum y_{i}}{n \cdot \sum x_{i}^{2}-\left(\sum x_{i}\right)^{2}} \quad b=\frac{\sum x_{i}^{2} \sum y_{i}-\sum x_{i} \sum x_{i} y_{i}}{n \cdot \sum x_{i}^{2}-\left(\sum x_{i}\right)^{2}}$

we obtain from the data in Tab 1a:

$y_{1}=-2 x+100$

and from the data in Tab $1 \mathrm{~b}$ :

$y_{2}=21.252 x+506.07$

Rewriting [1] in mathematical symbols we have:

$f: \quad y=x \cdot y_{1}-y_{2}$

Putting [3] and [4] into [5] we finally have the function of which the maximum is to be found: $y=x \cdot(-2 x+100)-(21.252 x+506.07)$

$y=-2 x^{2}+100 x-21.252 x-506.07$

$y=-2 x^{2}+78.748 x-506.07$

Further, using the differential calculus (although in this case just a formula for the co-ordinations of a vertex of a parabola would be sufficient) we look for the extremum. Putting the first derivative to be equal to zero and solving the equation we have:

$$
\begin{aligned}
y^{\prime} \equiv-4 x+78.748 & =0 \\
-4 x+78.748 & =0 \\
-4 x & =-78.748 \\
x & =19.687
\end{aligned}
$$

The second derivative $y^{\prime \prime}=-4$ which is less than zero, so the extremum is (local) maximum. In this case it is also a global maximum, because the function [6] is a parabola.

As the number of products cannot be a decimal number and knowing that the parabola is symmetric with respect to the axis passing through its vertex, the maximal profit will occur when the number of product will be 20 .

If the function will be of a different shape, rounding could not guarantee the correct solution, so one has to look for the values of $f(19)$ and $f(20)$. The values are 268.142 and 268.89 respectively. The greater one, 268.89 represents the maximal profit.

To sum up, as the Tab 1 shows the number of products in hundreds of pieces and the price in thousands of monetary units, to obtain maximal profit, the company has to produce 2000 products and then the profit will be of 268890 monetary units.

\section{Solving the problem with IT}

To solve the problem with the help of computers one may use different software with different possibilities. In this chapter we will briefly show, how to use MS Excel and, in more detail, how the problem could be solved with Wolfram Mathematica.

\section{a) Excel}

MS Excel is broadly accessible and the basics are taught in high schools. The help of Excel was discussed in (3), so in this chapter only some steps are shown. 
First the data from Tab. 1 should be entered into a spreadsheet and a graph should be created. In Img. 1 it is shown how to insert an XY Scatter chart.

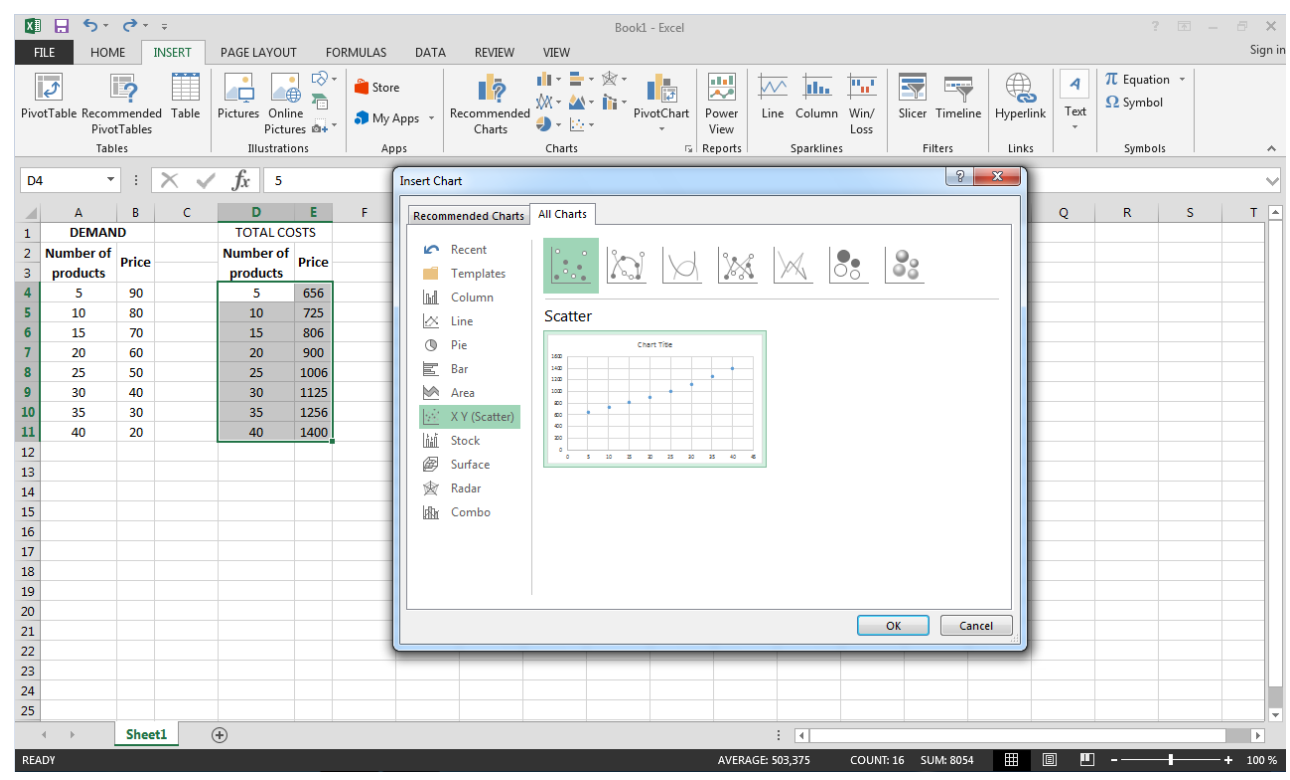

Image 1-Creating a graph in Excel (source: own)

Consequently, a trend line must be added. The way ho to do it is shown in Img. 2. There is a polynomial trend line of the order 2 . This is done intentionally because of two reasons: a) as it is seen from the graph, the quadratic polynomial fits the data with better accuracy than the linear regression (not shown) and $\mathrm{b}$ ) as we will see, this polynomial fit:

$y_{2}=0.25 x^{2}+10.002 x+599.82$

will lead to the same economical result as the linear fit used in the chapter 3 of this article.

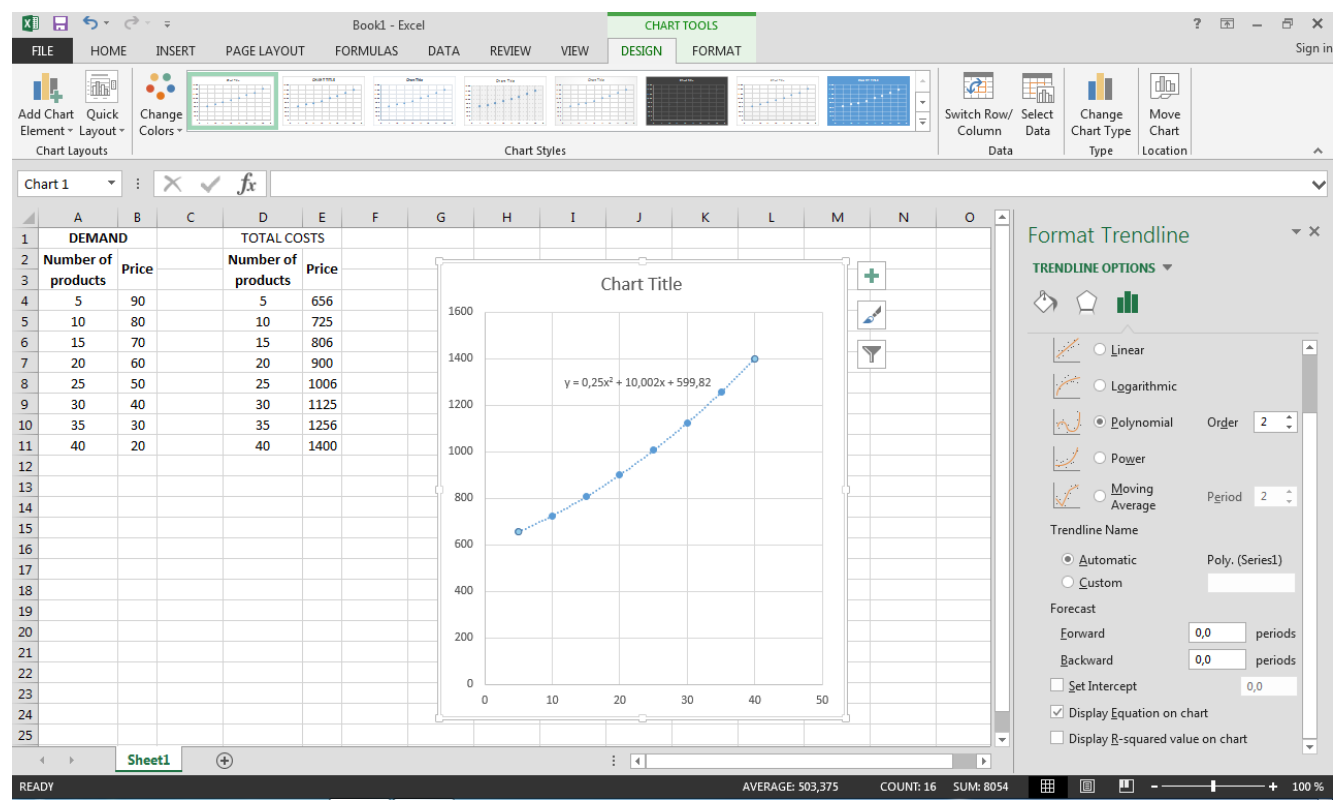

Image 2 - Adding a trend line and its equation into a graph. (source: own) 
Because Excel cannot calculate derivatives (unless one creates a macro in VBA performing numerical derivative), to solve the problem we have to leave IT and "come back" to finish the solution without computers.

Putting [3] and [8] into [5] leads to:

$$
\begin{aligned}
& y=x \cdot(-2 x+100)-\left(0.25 x^{2}+10.002 x+599.82\right) \\
& y=-2 x^{2}+100 x-0.25 x^{2}-10.002 x-599.82 \\
& y=-2.25 x^{2}+89.998 x-599.82
\end{aligned}
$$

Again, using the differential calculus to find extremum we continue:

$$
\begin{aligned}
y^{\prime} \equiv-4.5 x+89.998 & =0 \\
-4.5 x+89.998 & =0 \\
-4.5 x & =-89.998 \\
x & =19.9996
\end{aligned}
$$

Mathematically slightly different result, but the economical interpretation is the same: as $x$ must be a whole number, we round it to 20 .

\section{b) Mathematica}

Another option how to solve the given problem is to use a software and create a program which will perform all steps of the solution from the beginning to the very end including the calculations leading to finding of the maximum. In the following part the output of such a program is described. It is intended to present the program from the user's point of view, so the source code will not be discussed. For deeper interest in programing in Mathematica any appropriate publication, e.g. (1) is recommended.

After launching the program, three main panels are displayed.

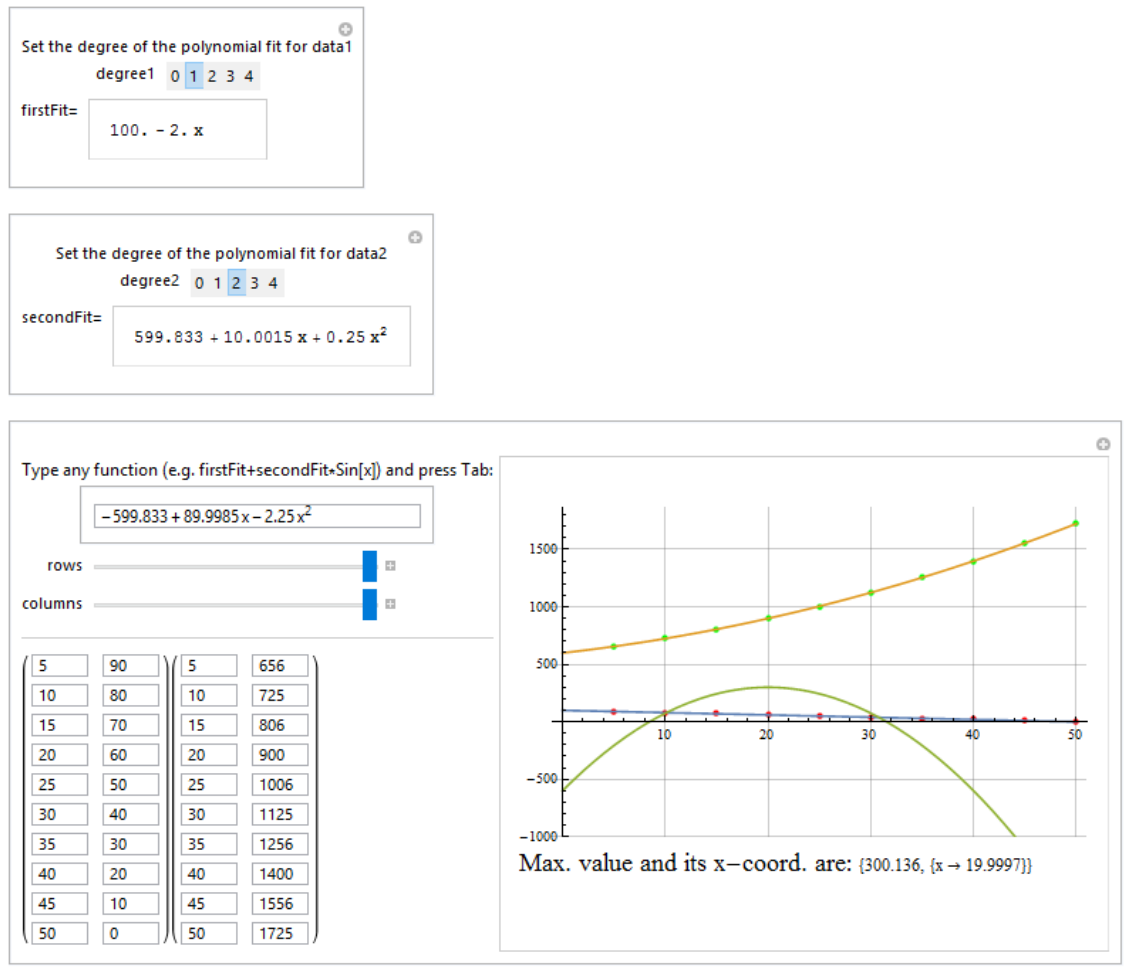

Image 3 - The output of the program in Mathematica (source: own) 
The program is designed to be user friendly. Thanks to the written instructions all checkboxes and sliders are intuitively to control and input fields easy to fill in.

At first, the user has to shift the sliders for rows and columns at the main panel of the Img. 1 to display as many boxes as needed for the input. Because the Tab. 1 contains two types of data (the demand and the total costs functions) and both of them have ten pairs of values, the rows slider should be set to 2 and the columns slider to 10 .

Next, the user has to enter the data given by Tab. 1 to the appropriate boxes. Once this is done, the users should choose the degree of the polynomials to fit data 1 and data 2 . This can by simply done by clicking on the numbered buttons situated on the first two panels. The graphs of the fitting curves, named as the firstFit and the secondFit are displayed in the main panel and so the user may visually check, how close the fit approximates the data.

Lastly the user types any function into the input field in the upper left part of the main panel. In our case it will be $x *$ firstFit-secondFit. The Mathematica will convert it automatically to the expression which is displayed in the input field in the Img. 3. As Mathematica calculates with better accuracy than Excel, one can see that the function slightly differs from the function [9]. The result is immediately calculated and shown at the bottom right part of the main panel.

The given data 1 and their firstFit are shown as red dots and a blue line respectively. The data 2 and their secondFit are shown as green dots and a yellow line respectively. The green line is then the "any function" typed by the user. Its maximum (the vertex) has coordinates of approximately [20,300] which represents the number of products to be produced: 20 to reach maximal profit: 300 .

\section{Conclusion}

The paper presents a simple economical problem and its mathematical model, which is solved by the help of IT and the result is interpreted.

As we have seen in chapters 3 and 4, different fit for the total costs function (compare [4] and [8]) has led to the same economic solution. From this fact a question arises, what is the appropriate fit for any given data? Should it be always the best fit, even if the mathematical model should be more complicated? Or is it better to use a more simple model, which will lead to more easy computational steps and still to the same economical result?

It is important to know that in cases like this, computer programs are only tools which help with calculations and visualization. But it is always the user who decides how to deal with the results.

\section{Bibliography}

1. DON, E. Schaum's outlines-Mathematica, 2ed.: McGraw-Hill, 2009. ISBN 978-0-07-160828-2

2. DOWLING, E.T. Schaum's outlines - Mathematical methods for business and economics.: McGraw-Hill, 1993. ISBN 0-07-017697-3

3. FAJKUS, M. Jak řešit jednoduchou optimalizační úlohu pomocí matematického modelu v Excelu. In Ivanková, T. Aplikované úlohy v modernom vyučovani matematiky. Zborník vedeckých prác. Nitra: Slovenská pol'nohospodárska univerzita v Nitre, 2012, pp.16-20. ISBN 978-80-552-0823-7.

4. ORSZÁGHOVÁ, D. Úlohy z matematickej analýzy v bakalárskom štúdiu na Fakulte ekonomiky a manažmentu SPU v Nitre. In 6. konference o matematice a fyzice na vysokých školách technických s mezinárodní účastí. Brno: Univerzita obrany, 2009, pp. 189--195. ISBN 978-807231-667-0

5. ORSZÁGHOVÁ, D. a kol. Matematika a jej aplikácie. Nitra: SPU v Nitre, 2010. ISBN 978-80552-0479-6

6. SLAVÍČKOVÁ, M. Using graphic calculus on calculus lessons. In Acta Didactica Universitatis Comenianae. Mathematics, Issue 9. Bratislava, 2009, pp.109-122 


\section{Address:}

Martin Fajkus, RNDr. Ph.D.

Ústav matematiky, Fakulta aplikované informatiky Univerzity Tomáše Bati ve Zlíně, Nad Stráněmi 4511, 76005 Zlín, ČR, tel.:+420 576035 064, e-mail: fajkus@ fai.utb.cz 